\title{
Effects of corn gluten feed inclusion at graded levels in a corn-soybean diet on the ileal and fecal digestibility of growing pigs
}

\author{
Gerardo Mariscal Landín ${ }^{*}$, Tércia Cesária Reis de Souza² and Ericka Ramírez Rodríguez ${ }^{1}$
}

\begin{abstract}
Background: This study aimed to determine the effect of the inclusion of corn gluten feed (CGF) on the apparent and standardized ileal digestibility of protein and amino acids and the apparent ileal and total tract digestibility of energy in growing pigs. The study was performed using 16 barrows (weight, $45.3 \pm 4.5 \mathrm{~kg}$ ) that were fitted with a T cannula at the terminal ileum. There were four treatments: a corn-soybean diet without CGF and three corn-soybean diets containing increasing levels of CGF (65, 130, and $195 \mathrm{~g} / \mathrm{kg})$. Data were analyzed according to a randomized complete block design, four blocks with four pigs each (one pig per treatment). The trend of the response (linear or quadratic) was determined using orthogonal contrasts, and when a linear effect was determined, a linear equation was obtained.

Results: The results showed that the inclusion up to $195 \mathrm{~g} / \mathrm{kg}$ of CGF in the corn-soybean diet did not diminish the ileal digestibility (apparent and standardized) of protein and amino acids $(P>0.05)$, except that of phenylalanine, cystine, and proline. A linear decrease $(P<0.05)$ per gram of CGF added to the diet in the apparent and standardized ileal digestibility of phenylalanine ( 0.011 and 0.015 percentage units, respectively), cystine ( 0.048 and 0.043 percentage units, respectively), and proline ( 0.045 and 0.047 percentage units, respectively) was noted. Similarly, ileal digestibility of dry matter and energy were adversely affected (reduced by 0.028 and 0.025 percentage units, respectively, per gram of CGF increment in the diet). A significant $(P<0.05)$ linear reduction in total tract digestibility with increase in CGF amount in the diet was observed for energy ( 0.027 percentage units), dry matter ( 0.027 percentage units), crude protein ( 0.020 percentage units), and neutral detergent fiber (0.041 percentage units) per gram of CGF added to the diet.
\end{abstract}

Conclusion: CGF did not affect the ileal digestibility of protein and most amino acids but reduced the ileal and total tract digestibility of energy.

Keywords: Amino acids, Corn gluten feed, Energy, lleal digestibility, Pigs, Total tract digestibility

\section{Background}

Corn (Zea mays) is the most harvested cereal worldwide [1]. Most of the corn produced is processed to extract flour, syrup, sweeteners, starches, oils, and ethanol. When wet milling is used to process corn, the germ is separated from the kernel, processed to obtain edible oil, and the resulting flour is mixed with the bran to produce corn gluten feed (CGF) [2], which has traditionally been considered a protein feed [3], although it is rich in fiber $[4,5]$. Therefore, the inclusion of CGF in pig diets has

\footnotetext{
* Correspondence: mariscal.gerardo@inifap.gob.mx

${ }^{1}$ Centro Nacional de Investigación en Fisiología Animal, Instituto Nacional de Investigaciones Forestales Agrícolas y Pecuarias, Km 1, Carretera a Colón, Ajuchitlán Colón, Querétaro 76280, México

Full list of author information is available at the end of the article
}

been limited, since fiber can affect directly [6,7] and indirectly $[8,9]$ the digestibility of amino acids by increasing endogenous protein losses. Thus, this study aimed to determine the effects of inclusion of CGF in a corn-soybean meal diet on the apparent and standardized ileal digestibility of amino acids and apparent total tract digestibility of energy in growing pigs. We hypothesized that the inclusion of CGF decreases the ileal digestibility of amino acids and energy and the total tract digestibility of energy.

\section{Materials and methods}

This study was approved by the Scientific Associate Technical Group Committee of CENID Physiology. The animals used in this study were cared for in accordance with the guidelines issued by the Mexican Official Standard 
for the Production, Protection and Use of Lab Animals [10] and the guidelines of the International Guiding Principles for Biomedical Research Involving Animals [11]. The study was performed at the experimental farm of CENID-Physiology.

\section{Animals}

Sixteen barrows (Duroc $\times$ Landrace) weighing $45.3 \pm 4.5 \mathrm{~kg}$ were used. The animals were placed in individual metabolic cages provided with a self-feeder and a low-pressure drinking nipple in a temperature controlled room at $20 \pm 2^{\circ} \mathrm{C}$. Animals were fed twice daily at $0800 \mathrm{~h}$ and $1800 \mathrm{~h}$ and had free access to water. A T cannula was fitted at the terminal ileum of each animal as previously described [12]. After surgery, therapeutic treatment (penicillin, 600,000 IU; streptomycin, 750 mg; oxytetracycline, $500 \mathrm{mg}$ ) was administered for $3 \mathrm{~d}$; the post-surgery period lasted $21 \mathrm{~d}$. From the second day after the post-surgery period, pigs began to receive $100 \mathrm{~g}$ of feed, which was increased by $100 \mathrm{~g} /$ day until the feed intake reached the level before surgery. During the experimental period the pigs were fed at 2.5-times the maintenance requirement of digestible energy of $460 \mathrm{~kJ} / \mathrm{kg} \mathrm{BW}^{0.75}$ [13]. Pigs had free access to water.

\section{Experimental diets}

The experimental diets were produced using corn, soybean meal, and CGF (Table 1). Four diets were formulated (Table 2) with increasing levels of CGF $(0,65$, 130 , and $195 \mathrm{~g} / \mathrm{kg}$ of diet) at the expenses of corn and soybean meal. Corn oil was included at a rate of $40 \mathrm{~g} / \mathrm{kg}$. Salt, vitamins, and minerals were included at the levels that met or exceeded the National Research Council (NRC) nutritional requirements [5]; chromic oxide was added at a rate of $3 \mathrm{~g} / \mathrm{kg}$ of feed as an inert marker [14]. The total fecal collection was performed daily for $5 \mathrm{~d}$ to achieve the required chromic oxide rate. Ferric oxide was added ( $3 \mathrm{~g} / \mathrm{kg}$ of diet) to the first meal of the fifth day (to mark the start of the collection period) as well as to the first meal of the eleventh day (to mark the end of the collection period) [15].

\section{Sample collection}

The experimental period lasted $12 \mathrm{~d}$; this included $5 \mathrm{~d}$ for adaptation to the diet, $5 \mathrm{~d}$ for the collection of feces, and $2 \mathrm{~d}$ for the collection of ileal digesta. Ileal digesta was collected in plastic bags (length, $11 \mathrm{~cm}$; width, $5 \mathrm{~cm}$ ) containing $10 \mathrm{~mL}$ of $0.2 \mathrm{~mol} / \mathrm{L}$ solution of $\mathrm{HCl}$ to block any bacterial activity. Bags were attached to the barrel of the cannula by using a rubber band. Ileal digesta was collected continuously over the course of $12 \mathrm{~h}$ each day. When the bags were filled, they were transferred to a container and frozen at $-20^{\circ} \mathrm{C}$ until lyophilization. All fecal samples were collected, frozen,
Table 1 Chemical composition of raw materials as fed-basis $(\mathbf{g} / \mathbf{k g})$

\begin{tabular}{|c|c|c|c|}
\hline Item & $\mathrm{SBM}^{1}$ & YC & CGF \\
\hline Dry matter & 899.5 & 900.3 & 891.2 \\
\hline Crude protein & 468.1 & 108.5 & 208.4 \\
\hline $\mathrm{NDF}^{2}$ & 89.5 & 119.7 & 338.7 \\
\hline $\mathrm{ADF}^{3}$ & 57.4 & 45.0 & 106.5 \\
\hline \multicolumn{4}{|l|}{ Amino acids } \\
\hline Alanine & 24.8 & 7.2 & 17.1 \\
\hline Aspartic acid & 67.5 & 9.7 & 17.3 \\
\hline Arginine & 42.6 & 8.2 & 12.1 \\
\hline Cystine & 8.3 & 2.7 & 4.3 \\
\hline Glutamic acid & 111.7 & 20.8 & 45.3 \\
\hline Glycine & 24.1 & 6.1 & 12.2 \\
\hline Histidine & 10.1 & 4.7 & 7.1 \\
\hline Isoleucine & 24.5 & 3.3 & 7.6 \\
\hline Leucine & 44.2 & 10.1 & 23.8 \\
\hline Lysine & 30.3 & 2.8 & 5.4 \\
\hline Methionine & 7.8 & 2.0 & 3.4 \\
\hline Phenylalanine & 28.9 & 4.7 & 9.7 \\
\hline Proline & 31.1 & 8.8 & 16.6 \\
\hline Serine & 30.7 & 5.7 & 11.5 \\
\hline Threonine & 27.9 & 5.6 & 12.1 \\
\hline Tyrosine & 20.8 & 3.9 & 8.1 \\
\hline Valine & 25.5 & 5.6 & 12.1 \\
\hline
\end{tabular}

${ }^{1}$ Raw materials: SBM = soybean meal, YC = yellow corn, $\mathrm{CGF}=$ corn gluten feed ${ }^{2} \mathrm{NDF}=$ neutral detergent fiber.

${ }^{3} \mathrm{ADF}=$ acid detergent fiber.

and kept at $-20^{\circ} \mathrm{C}$. At the end of the experimental period, the feces were defrosted and homogenized to obtain 10\% of the weight as a final sample for lyophilizing.

\section{Chemical analysis}

Ileal digesta and feces samples were lyophilized and ground in a laboratory mill by using a $0.5-\mathrm{mm}$ mesh (Arthur H. Thomas Co., Philadelphia, PA). Raw materials, experimental diets, ileal digesta, and feces were analyzed for dry matter (DM) and crude protein (CP) according to methods 934.01 and 976.05 of the Association of Official Agricultural Chemists (AOAC) [16]; neutral detergent fiber (NDF), according to van Soest [17]; and energy, by using an oxygen bomb calorimeter (model 1281; Parr, Moline, IL). Chromic oxide levels in the diets, ileal digesta, and feces were determined according to Fenton and Fenton [14]. Amino acid analysis was performed following method 994.12 of the AOAC [16]; samples were hydrolyzed in $6 \mathrm{~mol} / \mathrm{L} \mathrm{HCl}$ at $110^{\circ} \mathrm{C}$ for $24 \mathrm{~h}$. Methionine and cystine were oxidized with performic acid before the analysis. The amino acid analysis was performed according to 
Table 2 Composition and analyzed nutrient composition of experimental diets, as fed-basis $(\mathrm{g} / \mathrm{kg})$

\begin{tabular}{lllll}
\hline g CGF/kg feed & $\mathbf{0}$ & $\mathbf{6 5}$ & $\mathbf{1 3 0}$ & $\mathbf{1 9 5}$ \\
\hline Yellow corn & 762.9 & 716.9 & 671.2 & 625.6 \\
Soybean meal & 155.9 & 136.7 & 117.4 & 98 \\
Corn gluten feed & & 65.7 & 131 & 196.4 \\
Corn oil & 40.0 & 40.0 & 40.0 & 40.0 \\
Calcium carbonate & 17.9 & 19.2 & 20.5 & 21.9 \\
Dicalcium phosphate & 10.4 & 8.4 & 6.3 & 4.1 \\
Salt & 3.5 & 3.5 & 3.5 & 3.5 \\
L-Lysine HCl $^{\text {Tryptosine }}$ & 2.5 & 2.4 & 2.4 & 2.3 \\
Threonine $^{1}$ & 1.4 & 1.9 & 2.4 & 2.9 \\
Vitamins $^{1}$ & 0.2 & & & \\
Minerals $^{2}$ & 1.6 & 1.6 & 1.6 & 1.6 \\
Chromium oxide $^{2.5}$ & 0.7 & 0.7 & 0.7 & 0.7 \\
\end{tabular}

Chemical analysis

\begin{tabular}{|c|c|c|c|c|}
\hline Dry matter & 904.3 & 908.3 & 904.9 & 907.1 \\
\hline Protein & 128.7 & 127.7 & 140.2 & 135.7 \\
\hline Energy, MJ & 17.6 & 17.6 & 17.6 & 17.2 \\
\hline NDF & 103.5 & 121.8 & 138.3 & 149.2 \\
\hline \multicolumn{5}{|l|}{ Amino acids } \\
\hline Alanine & 7.4 & 8.5 & 9.8 & 9.2 \\
\hline Arginine & 8.8 & 9.8 & 11.0 & 9.6 \\
\hline Aspartic acid & 13.5 & 14.0 & 15.5 & 13.3 \\
\hline Cystine & 2.9 & 2.9 & 2.7 & 2.4 \\
\hline Glutamic acid & 24.1 & 27.1 & 31.6 & 28.0 \\
\hline Glycine & 6.6 & 7.2 & 8.1 & 7.4 \\
\hline Histidine & 3.9 & 4.6 & 4.9 & 5.0 \\
\hline Isoleucine & 2.6 & 4.3 & 5.3 & 5.0 \\
\hline Leucine & 9.8 & 12.3 & 14.4 & 13.3 \\
\hline Lysine & 9.3 & 9.8 & 9.8 & 9.4 \\
\hline Methionine & 1.8 & 1.7 & 1.7 & 1.4 \\
\hline Phenylalanine & 5.3 & 6.2 & 7.1 & 6.1 \\
\hline Proline & 8.3 & 11.8 & 12.2 & 8.4 \\
\hline Serine & 7.3 & 7.6 & 8.8 & 7.5 \\
\hline Threonine & 6.4 & 6.9 & 7.8 & 7.1 \\
\hline Tyrosine & 4.3 & 5.2 & 5.8 & 5.0 \\
\hline Valine & 3.8 & 6.3 & 7.4 & 7.3 \\
\hline
\end{tabular}

${ }^{1}$ Provided per kg piglet diet: $\mathrm{Cl}, 1.65 \mathrm{~g} ; \mathrm{Na}, 0.87 \mathrm{~g} ; \mathrm{Cu}, 7.7 \mathrm{mg} ; \mathrm{Fe}, 89.25 \mathrm{mg} ; \mathrm{Mn}$, $19.98 \mathrm{mg}$; Se, $0.087 \mathrm{mg}$; l, $0.053 \mathrm{mg}$.

${ }^{2}$ Provided per kg piglet diet: vitamin A, $6600 \mathrm{IU}$; vitamin D, $660 \mathrm{IU}$; vitamin E, $100 \mathrm{IU}$; choline, $350 \mathrm{mg}$; niacin, $54 \mathrm{mg}$; pantothenic acid, $13.15 \mathrm{mg}$; riboflavin, $2.2 \mathrm{mg} ; \mathrm{B}_{12}, 36 \mathrm{~g}$.

NDF = neutral detergent fiber.

the method reported by Henderson et al. [18] by using a high-performance liquid chromatography (HPLC) model (1100; Hewlett Packard).

\section{Data analysis}

Apparent ileal or total tract digestibility (AID or ATTD) were estimated using the equation proposed by Fan and Sauer [19].

$$
A I D=[1-[(I D \times A F) /(A D \times I F)]] \times 100,
$$

where AID\% is the apparent (ileal or total) digestibility of a nutrient in the diet, $I D$ is the marker concentration in the diet (mg/kg of DM), $A F$ is the concentration of nutrient in the ileal digesta or feces ( $\mathrm{mg} / \mathrm{kg}$ of $\mathrm{DM}), A D$ is the concentration of the nutrient in the diet $(\mathrm{mg} / \mathrm{kg}$ of $\mathrm{DM}$ ), and $I F$ is the marker concentration in the ileal digesta or feces ( $\mathrm{mg} / \mathrm{kg}$ of DM).

The standardized ileal digestibility (SID) was obtained using the formula proposed by Furuya and Kaji [20].

$$
S I D=A I D+(\text { Endogenous } / \text { Dietary Content })
$$

where $S I D$ is the standardized ileal digestibility of a nutrient, $A I D$ is the coefficient of apparent ileal digestibility of a nutrient, and Endogenous is the endogenous ileal losses of a nutrient in $\mathrm{mg} / \mathrm{kg}$ of dry matter intake. The calculations were performed using endogenous values reported by Mariscal-Landin and Reis de Souza [21]. Dietary Content is the amount of nutrient consumed in $\mathrm{mg} / \mathrm{kg}$ of dry matter intake.

\section{Statistical analysis}

Data were analyzed according to a randomized complete block design [22] by using the general linear model (GLM) procedure of statistical analysis system (SAS) [23]: four blocks with four pigs each (one pig per treatment). Each pig was the experimental unit, and an alpha value of 0.05 was used to assess the significance. The trend of the response (linear or quadratic) was determined using orthogonal contrasts [22]. When a linear effect was determined, a linear equation was obtained using the regression (REG) procedure of SAS [23].

\section{Results}

\section{Apparent ileal digestibility}

The results of apparent ileal digestibility are shown in Table 3. The inclusion of CGF significantly reduced $(P<0.05)$ the AID of dry matter; there was a reduction of 5.7 percentage units between the diet without CGF and the diet containing $195 \mathrm{~g}$ of CGF (87.7\% vs. 82.0\%). This adverse effect was also observed in energy digestibility, which was reduced by 4.9 percentage units (from 88.8 to 83.9 in the diets with 0 or $195 \mathrm{~g}$ of CGF, respectively). The digestibility of phenylalanine, cystine and proline decreased linearly $(P<0.05)$ in response to CGF increment in the diet. The average reduction in ileal digestibility of amino acids was 0.031 percentage units per gram of CGF included in the diet. Cystine digestion was the most 
Table 3 Apparent ileal digestibility (AID) coefficients (\%) of experimental diets

\begin{tabular}{|c|c|c|c|c|c|}
\hline g CGF/kg feed & 0 & 65 & 130 & 195 & SEM \\
\hline Dry matter ${ }^{A}$ & 87.7 & 83.8 & 82.8 & 82.0 & 0.66 \\
\hline Protein & 84.9 & 81.4 & 81.7 & 80.7 & 0.98 \\
\hline Energy $^{A}$ & 88.8 & 86.0 & 84.6 & 83.9 & 0.66 \\
\hline \multicolumn{6}{|l|}{ Amino acids } \\
\hline Alanine & 82.4 & 81.1 & 80.3 & 81.5 & 1.31 \\
\hline Arginine & 93.1 & 91.9 & 91.0 & 89.5 & 0.86 \\
\hline Aspartic acid & 86.1 & 83.1 & 83.1 & 81.5 & 1.05 \\
\hline Cystine $^{\mathrm{A}}$ & 86.1 & 85.1 & 81.8 & 76.7 & 1.22 \\
\hline Glutamic acid & 88.7 & 88.1 & 87.7 & 86.9 & 0.92 \\
\hline Glycine & 80.2 & 79.3 & 77.5 & 76.3 & 1.38 \\
\hline Histidine & 87.5 & 86.7 & 85.7 & 85.7 & 0.91 \\
\hline Isoleucine & 79.0 & 83.5 & 83.1 & 83.1 & 1.63 \\
\hline Leucine & 87.4 & 87.4 & 87.4 & 86.9 & 1.03 \\
\hline Lysine & 92.7 & 90.8 & 90.6 & 90.6 & 0.67 \\
\hline Methionine & 83.3 & 82.4 & 82.1 & 78.2 & 1.20 \\
\hline Phenylalanine $^{A}$ & 93.7 & 92.1 & 92.0 & 91.4 & 0.30 \\
\hline Proline ${ }^{A}$ & 87.5 & 89.1 & 83.9 & 79.6 & 1.27 \\
\hline Serine & 85.5 & 82.8 & 82.7 & 81.1 & 1.18 \\
\hline Threonine & 81.9 & 77.8 & 77.5 & 77.2 & 1.52 \\
\hline Tyrosine & 88.2 & 88.1 & 87.3 & 85.9 & 0.94 \\
\hline Valine & 79.8 & 85.2 & 84.1 & 83.5 & 1.57 \\
\hline
\end{tabular}

affected (0.048 percentage units) and phenylalanine, the least ( 0.011 percentage units). The digestibility of the other amino acids was not affected by the inclusion of CGF at the levels used in this study.

\section{Standardized ileal digestibility}

The standardized ileal digestibility of amino acids is shown in Table 4. In general, the inclusion of CGF in the diet did not affect $(P>0.05)$ the SID. However, a linear decrease in SID of phenylalanine (0.015 percentage units; from 98.7 to 95.8$)$, cystine (0.043 percentage units, from 91.4 to 83.1 ), and proline (0.047 percentage units, from 103.7 to 94.9 ) was noted per gram inclusion of CGF. There was no significant reduction in the digestibility of the other amino acids $(P>0.05)$.

\section{Apparent total tract digestibility}

The ATTD of dry matter, protein, energy, and NDF diminished $(P<0.05)$ linearly with an increase in CGF concentration in the diet (Table 5). The effect of CGF inclusion on ATTD was net and clear. The reduction of digestibility of dry matter and energy was 6.7 percentage units; for protein, 6.3 percentage units; and for NDF, 11.3 percentage units. The linear equations are shown in
Table 4 Standardized ileal digestibility (SID) coefficients (\%) of experimental diets

\begin{tabular}{|c|c|c|c|c|c|}
\hline g CGF/kg feed & 0 & 65 & 130 & 195 & SEM \\
\hline Protein & 93.7 & 90.3 & 89.9 & 89.1 & 0.98 \\
\hline \multicolumn{6}{|l|}{ Amino acids } \\
\hline Alanine & 87.6 & 85.7 & 84.3 & 85.7 & 1.31 \\
\hline Aspartic acid & 91.2 & 88.0 & 87.4 & 86.6 & 1.05 \\
\hline Arginine & 97.1 & 95.5 & 94.7 & 92.7 & 0.86 \\
\hline Cystine $^{A}$ & 91.4 & 90.3 & 87.3 & 83.1 & 1.22 \\
\hline Glutamic acid & 91.9 & 91.0 & 90.1 & 89.7 & 0.92 \\
\hline Glycine & 92.0 & 89.9 & 86.9 & 86.8 & 1.38 \\
\hline Histidine & 91.8 & 90.3 & 89.2 & 89.1 & 0.91 \\
\hline Isoleucine & 90.3 & 90.5 & 89.0 & 88.9 & 1.63 \\
\hline Leucine & 92.5 & 92.0 & 90.9 & 90.6 & 1.03 \\
\hline Lysine & 96.8 & 94.2 & 94.2 & 93.5 & 0.67 \\
\hline Methionine & 87.2 & 86.2 & 86.6 & 83.2 & 1.20 \\
\hline Phenylalanine $^{\mathrm{A}}$ & 98.7 & 96.5 & 95.8 & 95.8 & 0.30 \\
\hline Proline $^{\mathrm{A}}$ & 103.7 & 100.5 & 95.5 & 94.9 & 1.27 \\
\hline Serine & 92.4 & 89.3 & 88.4 & 87.9 & 1.18 \\
\hline Threonine & 90.8 & 86.0 & 85.6 & 84.5 & 1.52 \\
\hline Tyrosine & 91.4 & 90.7 & 89.7 & 88.7 & 0.94 \\
\hline Valine & 90.3 & 91.6 & 89.5 & 89.0 & 1.57 \\
\hline
\end{tabular}

${ }^{A}$ Linear effect $(P<0.05)$.

Table 6; a decrease of 0.02 to 0.03 percentage units in the ATTD of DM, CP, and energy per gram of CGF included in the diet and a decrease of 0.041 percentage units in the ATTD of NDF were noted per gram of CGF included in the diet.

\section{Discussion}

Fiber has been defined as "vegetal compounds, from carbohydrate nature and resistant to digestive enzymes"; it is classified according to solubility as soluble fiber ( $\beta$-glucans, gums, and mucilages) and insoluble fiber (cellulose and most hemicelluloses) [24]. CGF is a mixture of corn structures that remain after the removal of most starch and gluten germ [2]. Approximately, two-thirds of these corn structures are fibrous structures, and one-third consists of soluble compounds [25]. The fiber obtained from corn is essentially insoluble ( $99 \%$ of the total fiber)

Table 5 Apparent total tract digestibility (ATTD) coefficients (\%) of experimental diets

\begin{tabular}{llllll}
\hline $\mathbf{g ~ C G F / k g ~ f e e d ~}$ & $\mathbf{0}$ & $\mathbf{6 5}$ & $\mathbf{1 3 0}$ & $\mathbf{1 9 5}$ & SEM \\
\hline Dry matter $^{\mathrm{A}}$ & 88.6 & 81.3 & 83.7 & 81.9 & 0.36 \\
Protein $^{\mathrm{A}}$ & 86.9 & 76.9 & 83.4 & 80.6 & 0.59 \\
Energy $^{\mathrm{A}}$ & 88.7 & 81.4 & 84.1 & 82.0 & 0.36 \\
NDF $^{\mathrm{A}}$ & 62.5 & 47.8 & 55.2 & 51.2 & 1.42 \\
\hline
\end{tabular}

A Linear effect $(P<0.05)$.

$\mathrm{NDF}=$ neutral detergent fiber. 
Table 6 Linear relationships between corn gluten feed (CGF) inclusion and ileal and total tract digestibility coefficients Apparent ileal digestibility

$\begin{array}{lll}\text { Dry matter } & \text { DM }=86.77( \pm 1.02)-0.028( \pm 0.008) \mathrm{gCGF}{ }^{1} & r^{2}=0.86 \\ \text { Energy } & \mathrm{E}=88.22( \pm 0.96)-0.025( \pm 0.008) \mathrm{gCGF} & r^{2}=0.92 \\ \text { Phenylalanine } & \text { Phe }=93.31( \pm 0.46)-0.011( \pm 0.004) \mathrm{gCGF} & r^{2}=0.84 \\ \text { Cystine } & \text { Cys }=87.15( \pm 1.90)-0.048( \pm 0.016) \mathrm{gCGF} & r^{2}=0.92 \\ \text { Proline } & \text { Pro }=89.36( \pm 1.89)-0.045( \pm 0.016) \mathrm{gCGF} & r^{2}=0.78 \\ \text { Standardized ileal digestibility } & & r^{2}=0.78 \\ \text { Phenylalanine } & \text { Phe }=98.13( \pm 0.51)-0.015( \pm 0.004) \mathrm{gCGF} & r^{2}=0.94 \\ \text { Cystine } & \text { Cys }=92.19( \pm 1.88)-0.043( \pm 0.015) \mathrm{gCGF} & r^{2}=0.93 \\ \text { Proline } & \text { Pro }=103.20( \pm 1.84)-0.047( \pm 0.015) \mathrm{gCGF} & r^{2}=0.47 \\ \text { Apparent total tract digestibility } & & r^{2}=0.14 \\ \text { Dry matter } & \mathrm{DM}=86.52( \pm 1.16)-0.027( \pm 0.010) \mathrm{gCGF} & r^{2}=0.46 \\ \text { Protein } & \mathrm{CP}=83.85( \pm 1.74)-0.020( \pm 0.014) \mathrm{gCGF} & r^{2}=0.29 \\ \text { Energy } & \mathrm{E}=86.64( \pm 1.20)-0.027( \pm 0.010) \mathrm{gCGF} & \\ \text { NDF } & \mathrm{NDF}=58.13( \pm 2.97)-0.041( \pm 0.015) \mathrm{gCGF} & \end{array}$

${ }^{1} \mathrm{gCGF}=$ grams of corn gluten feed added to the diet.

$\mathrm{NDF}=$ neutral detergent fiber.

and represents over $30 \%$ of the dry matter [25]; the CGF used in this study had $338.7 \mathrm{~g} \mathrm{NDF} / \mathrm{kg}$. Insoluble fiber is known to cause endogenous protein losses and reduce the AID of protein and amino acids because it increases mucin secretion as well as mucosal cell shedding via its abrasive effect $[8,26,27]$. The protein content of CGF is not contained in the fibrous part (bran). It is present in the soluble fraction that is mixed with bran at the end of the milling process [2]; therefore, fiber does not block the enzyme access to proteins as is noted in wheat bran, in which a high proportion of protein is present in the aleurone cells [28]. Furthermore, several authors [29-31] have suggested that insoluble fiber has a minor effect on the ileal digestibility of amino acids and protein. Both findings (protein is not present in the fibrous part and the minor effect of insoluble fiber on the ileal digestibility of protein) could explain the almost null effect of CGF on the ileal digestibility of protein and amino acids. The decrease in the ileal digestibility of proline could be because of the proteins present in the fibrous fraction; these proteins are rich in extensine-a proline-rich protein that resembles collagen-and are closely linked to the cellulose fraction [32-34]. The negative effect on the ileal digestibility of dry matter and energy was due to an increase in the levels of non-digestible compounds (insoluble fiber) after treatment with CGF; as mentioned before, two-thirds of the CGF is insoluble fiber, and hence, it dilutes the digestible dry matter and energy as has been reported previously [35].

In the large intestine, the undigested food (mainly non-starch polysaccharides and protein) is fermented by microorganisms [36]. This is a long process, but the insoluble fiber decreases the residence time of digesta in the cecum and colon, and this effect is related to the fiber content of the diet $[24,29,35]$. Insoluble fibers are resistant to fermentation; therefore, they play a major role in fecal bulking, unlike soluble fibers that are almost completely fermented and have little effect on increasing fecal bulk [37]. This limited fermentation of insoluble fibers by intestinal bacteria reduces the total digestibility of protein and energy [31,35,38]; consequently, the digestible energy is low in diets containing CGF. Furthermore, fibers increase the production of mucin, an almost indigestible protein, thereby increasing protein excretion in the feces [39] and lowering protein digestion. As discussed before, the inclusion of CGF in diets has a mild effect on the ileal digestibility of amino acids; however, it adversely affects energy digestibility. Few studies have quantitatively investigated the adverse effect of NDF on energy digestibility; the findings reported in this study are in agreement with those reported by Dégen [31]. However, in sows, fiber plays an important role in avoiding stereotyped conducts, and thus, sows are able to obtain more energy from fiber than growing pigs $[24,40,41]$.

\section{Conclusions}

CGF did not affect the apparent and standardized ileal digestibility of protein and most amino acids, except that of phenylalanine, cystine, and proline. However, it linearly decreased the ileal digestibility of energy and the total tract digestibility of protein and energy.

\section{Abbreviations}

CGF: Corn gluten feed; AID: Apparent ileal digestibility; SID: Standardized ileal digestibility; ATTD: Apparent total tract digestibility; NDF: Neutral detergent fiber.

\section{Competing interests}

The authors declare that they have no competing interests. 


\section{Authors' contributions}

GML conceived and designed the study; ERR carried out laboratory analysis; TCRS contributed to data analysis; GML and TCRS drafted the manuscript. All authors read and approved the final manuscript.

\section{Acknowledgments}

This study was funded in part by the Ministry of Agriculture, Livestock and Fishing (SAGARPA) of Mexico and The National Council for Science and Technology (CONACYT) of Mexico via the financial support provided to Research Project SAGARPA-CONACYT 2003-2-169.

\section{Author details}

'Centro Nacional de Investigación en Fisiología Animal, Instituto Nacional de Investigaciones Forestales Agrícolas y Pecuarias, Km 1, Carretera a Colón,

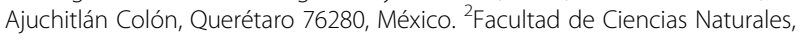
Universidad Autónoma de Querétaro, Santiago de Querétaro, Av. De las Ciencias s/n Juriquilla 76000, Querétaro, Querétaro, México.

Received: 27 March 2014 Accepted: 11 August 2014

Published: 20 August 2014

\section{References}

1. FAO: FAOSTAT Organización de las Naciones Unidas para la Alimentación y la Agricultura. 2010.

2. Blasi DA, Drouillard J, Brouk MJ, Montgomory SP: Corn Gluten Feed, Composition and Feeding Value for Beef and Dairy Cattle. In Corn Gluten Feed, Composition and Feeding Value for Beef and Dairy Cattle. Manhattan: Kansas State University; 2001. 14 pages.

3. Yen JT, Brooks JD, Jensen AH: Metabolizable energy value of corn gluten feed. J Anim Sci 1974, 39:335-337.

4. INRA: Tables de composition et de valeur nutritive des matières premières destinées aux animaux d'élevage. Porcs, volailles, bovins, ovins, caprins, lapins, chevaux, poissons. Paris, France: Institut National de la Recherche Agronomique; 2002.

5. NRC: Nutrient requirements of swine. 10th edition. Washington, DC: The National Academy Press; 1998.

6. Ma QG, Metzler BU, Eklund M, Ji C, Mosenthin R: The effects of cellulose, pectin and starch on standardized ileal and apparent total tract amino acid digestibilities and bacterial contribution of amino acids in feces of growing pigs. Asian-Aust J Anim Sci 2008, 21:873-882.

7. Myrie SB, Bertolo RF, Sauer WC, Ball RO: Effect of common antinutritive factors and fibrous feedstuffs in pig diets on amino acids digestibilities with special emphasis in threonine. J Anim Sci 2008, 86:609-619.

8. Mariscal-Landín G, Reis de Souza TC, Hernández DAA, Escobar GK: Pérdidas endógenas de nitrógeno y aminoácidos en cerdos y su aplicación en la estimación de los coeficientes de digestibilidad ileal de la proteína y aminoácidos de las materias primas. Téc Pecu Méx 2009, 47:371-388.

9. Schulze H, van Leeuwen P, Verstegen MWA, Huisman J, Souffrant WB, Ahrens F: Effect of level of dietary neutral detergent fiber on ileal apparent digestibility and ileal nitrogen losses in pigs. J Anim Sci 1994, 72:2362-2368.

10. Diario Oficial de la Federación: Especificaciones técnicas para la producción, cuidado y uso de los animales de laboratorio. Norma Oficial Mexicana NOM-062-ZOO-1999. Diario Oficial de la Federación, Segunda Sección, Miércoles 22 de Agosto 2001.

11. International guiding principles for biomedical research involving animals. In The development of science-based guidelines for laboratory animal care-NCBI Bookshelf. [http://cioms.ch/publications/guidelines/1985_texts_of_guidelines.htm].

12. de Reis de Souza TC, Mar BB, Mariscal LG: Canulación de cerdos posdestete para pruebas de digestibilidad ileal: Desarrollo de una metodología. Téc Pecu Méx 2000, 38:143-150.

13. INRA: L'alimentation des animaux monogastriques: porc, lapin, volailles. Paris, France: Institut National de la Recherche Agronomique; 1984.

14. Fenton TW, Fenton M: An improved procedure for determination of chromic oxide in feed and feces. Can J Anim Sci 1979, 59:631-634.

15. Adeola O: Digestion and balance technique in pigs. In Swine Nutrition. 2nd edition. Edited by Lewis AJ, Southern LL. Boca Raton, USA: CRC PresS; 2001:903-916

16. AOAC: Official Methods of Analysis. 17th edition. Arlington, VA. USA: Assoc. Offic. Anal. Chem; 2000

17. van Soest PJ, Robertson JB, Lewis BA: Methods for dietary fiber, neutral detergent fiber, and nonstarch polysaccharides in relation to animal nutrition. J Dairy Sci 1991, 74:3583-3597.
18. Henderson $\mathrm{JH}$, Ricker RD, Bidlingmeyer BA, Woodward C: Rapid, accurate and reproducible HPLC analysis of amino acids. Amino acid analysis using Zorbax Eclipse AAA columns and the Agilent 1100 HPLC. Agilent technologies 2000. 10 pag. Agilent technologies homepage [www.agilent.com/chem/supplies].

19. Fan MZ, Sauer WC: Determination of apparent ileal amino acid digestibility in barley and canola meal for pigs with the direct, difference, and regression methods. J Anim Sci 1995, 73:2364-2374.

20. Furuya S, Kaji Y: Estimation of the true ileal digestibility of amino acids and nitrogen from their apparent values for growing pigs. Anim Feed Sci Technol 1989, 26:271-285.

21. Mariscal-Landín G, Reis de Souza TC: Endogenous ileal losses of nitrogen and amino acids in pigs and piglets fed graded levels of casein. Arch Anim Nutr 2006, 60:454-466.

22. Steel RGD, Torrie JH: Principles and procedures of statistics. A Biometrical approach. 2nd edition. New York: McGraw-Hill; 1980.

23. SAS version 9.2: Book Statistical Analysis Systems Institute User's guide. 92nd edition. Cary NC: SAS Institute Inc; 2008.

24. Le Gall M, Montagne L, Meunier-Salaün MC, Noblet J: Valeurs nutritives des fibres, conséquences sur la santé du porcelet et le bien-être de la truie. INRA Prod Anim 2009, 22:17-24

25. Kawauchi IM, Sakomura NK, Vasconcellos RS, de-Oliveira LD, Gomes MOS, Loureiro BA, Carciofi AC: Digestibility and metabolizable energy of maize gluten feed for dogs as measured by two different techniques. Anim Feed Sci Technol 2011, 169:96-103.

26. Mariscal-Landín G, Sève B, Collèaux Y, LeBreton Y: Endogenous amino nitrogen collected from pigs with end to end ileorectal anastomosis is affected by the method of estimation and altered by dietary fiber. J Nutr 1995, 125:136-146.

27. Reverter M, Lindberg JE: Ileal digestibility of amino acids in pigs given a barley-based diet with increasing inclusion of Lucerne meal. Anim Sci 1998, 67:131-138.

28. Laubin B, Lullien-Pellerin V, Nadaud I, Gaillard-Martinie B, Chambon C, Branlard G: Isolation of the wheat aleurona layer for $2 \mathrm{D}$ electrophoresis and proteomic analysis. J Cereal Sci 2008, 48:709-714.

29. Bach Knudsen KE: The nutritional significance of "dietary fibre" analysis. Anim Feed Sci Technol 2001, 90:3-20.

30. Li S, Sauer WC, Hardin RT: Effect of dietary fibre level on amino acid digestibility in young pigs. Can J Anim Sci 1994, 74:327-333.

31. Dégen $L$, Halas $B$, Babinszky $L$ : Effect of dietary fibre on protein and fat digestibility and its consequences on diet formulation for growing and fattening pigs: A review. Acta Agric Scand Sect A Anim Sci 2007, 57:1-9.

32. Sun T, Li S, Ren H: Profilin as a regulator of the membrane-actin cytoskeleton interface in plant cells. Front Plant Sci 2013, 4:512.

33. Williamson MP: The structure and function of proline-rich regions in proteins. Biochem J 1994, 297:249-260.

34. Bjergegaar C, Sørensen $H$, Sørensen S: Dietary fibres-important parts of high quality food and feeds. J Anim Feed Sci 1997, 6:145-161.

35. Ngoc T, Len N, Lindberg J: Impact of fibre intake and fibre source on digestibility, gut development, retention time and growth performance of indigenous and exotic pigs. Animal 2013, 7:736-745.

36. Caspar W: The role of dietary fibre in the digestive physiology of the pig. Anim Feed Sci Technol 2001, 90:21-33.

37. Wong J, Jenkins D: Carbohydrate digestibility and metabolic effects. J Nutr 2007, 137:2539S-2546S

38. Hansen MJ, Chwalibog A, Tausson AH, Sawosz E: Influence of different fibre sources on digestibility and nitrogen and energy balances in growing pigs. Arch Anim Nutr 2006, 60:390-401.

39. Montagne L, Piel C, Lallès JP: Effect of Diet on Mucin Kinetics and Composition: Nutrition and Health Implications. Nutr Rev 2004, 62:105-114.

40. Shi XS, Noblet J: Digestible and metabolizable energy values of ten feed ingredients in growing pigs fed ad libitum and sows fed at maintenance level; comparative contribution of the hindgut. Anim Feed Sci Technol 1993, 42:223-236.

41. Kerr BJ, Shurson GC: Strategies to improve fiber utilization in swine. J Anim Sci Biotechnol 2013, 4:11.

doi:10.1186/2049-1891-5-40

Cite this article as: Mariscal Landín et al:: Effects of corn gluten feed inclusion at graded levels in a corn-soybean diet on the ileal and fecal digestibility of growing pigs. Journal of Animal Science and Biotechnology 2014 5:40. 